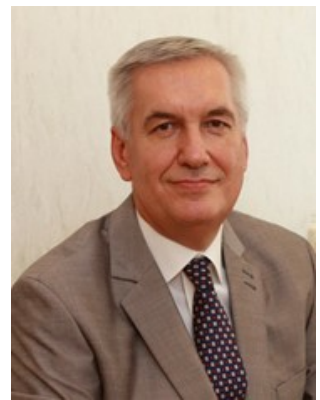

\author{
Volodymyr \\ KRYVOLAPCHUK ${ }^{\odot}$ \\ Dr of Law, Prof.
}

\author{
Ruslan FYL ${ }^{\odot}$ \\ Dr of Law
}

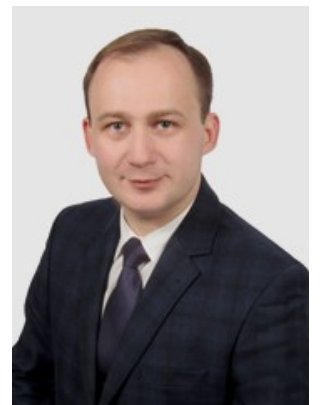

(State Research Institute of the Ministry of Internal Affairs of Ukraine)

\title{
PROBLEM ISSUES ON THE PROTECTION OF INTELLECTUAL PROPERTY RIGHTS IN THE PHARMACEUTICAL INDUSTRY OF UKRAINE
}

Володимир Криволапчук, Руслан Филь. ПРОБЛЕМНІ ПИТАННЯ ОХОРОНИ ПРАВ ІНТЕЛЕКТУАЛЬНОЇ ВЛАСНОСТІ У ФАРМАЦЕВТИЧНІЙ ГАЛУЗІ УКРАЇНИ. У стаТТі висвітлено актуальні проблеми охорони прав інтелектуальної власності у вітчизняній фармацевтичній галузі. Розкрито ефективність використання інноваційних лікарських засобів у сфері охорони здоров'я. Проаналізувавши норми міжнародного та національних законодавства, розкрито зміст фармацевтичної продукції як об’єкта прав інтелектуальної власності в Україні та визначено стан національного правового механізму захисту прав інтелектуальної діяльності у сфері фармації. Використовуючи системний та формально-логічний методи, охарактеризовано процедуру примусового ліцензування запатентованих винаходів (корисних моделей) та сформовано основні проблеми ії реалізації.

3'ясовано, що основними проблемами охорони прав інтелектуальної власності у вітчизняній фармацевтичній галузі $\epsilon$, зокрема: неефективність державної політики стосовно розвитку інноваційних лікарських засобів; відсутність прозорого та зрозумілого механізму видачі примусової ліцензії запатентованих винаходів; суспільна необізнаність про ефективність застосування інновацій в охороні здоров'я як для держави, так і пацієнта; обмеженість у доступі українських пацієнтів до інноваційних ліків та методів лікування. Для подолання окреслених проблем та 3 урахуванням євроінтеграції України, наша держава зобов'язалась гармонізувати національну систему охорони та захисту прав інтелектуальної власності відповідно до гл. 9 «Інтелектуальна власність» Угоди про асоціацію між Україною та ЄС. Встановлення дієвого механізму охорони прав інтелектуальної власності на лікарські засоби, стимулюватиме розвиток інноваційної фармацевтичної продукції. Адже, розроблення сучасних медичних препаратів потребує залучення колосальних коштів, для виділення яких, як для вітчизняних, так й іноземних виробників фармацевтичної продукції необхідні гарантії захисту їх інвестицій та прав інтелектуальних результатів.

Ключові слова: лікарські засоби, права інтелектуальної власності, охорона прав, фармачевтична галузь.

Problem statement. The pharmaceutical industry is one of the most important components of healthcare for which the patient's best interests always come first. Pharmacy also plays a significant role in Ukraine's economy, as it is an important segment of the domestic market and national security of the country. Providing Ukrainians with high-quality and affordable medicines is a paramount state and social task that cannot be solved without stable and progressive development of pharmaceutical activity.

Since independence, the domestic pharmaceutical industry has undergone significant positive changes in the production and development of the newest medicines, the accessibility of which to the population, according to research by the Organization for Economic Co-

(C) Kryvolapchuk V., 2019

ORCID iD: https://orcid.org/0000-0001-9449-2242

dndi@mvs.gov.ua

(C) Fyl R., 2019

ORCID iD: https://orcid.org/0000-0002-5680-875X

dndi@mvs.gov.ua 
operation and Development, the European Federation of Associations of Pharmaceutical Manufacturers and the European Statistical Organization, directly affects the quality and life expectancy [1]. Thus, according to the study by Professor F. Lichtenberg Columbia University, the use of innovative medicines and the latest treatments for cardiovascular disease and cancer in 52 countries has extended life expectancy by $40-59 \%$ [16].

The availability of innovative medicines and cutting-edge therapeutic solutions is critical to the successful delivery of healthcare. After all, thanks to timely and effective treatment, a person can return to a normal full life.

In Ukraine, the cost of developing innovative medicines is extremely low compared to European countries. The imperfection of national pharmaceutical activity is also evidenced by the fact that currently only $5 \%$ of medicines in Ukraine are original. The lack of understanding of the importance of innovation for the pharmaceutical industry and the lack of legal protection of intellectual property rights create barriers not only to the development of new innovative medicines, but also to the entry of foreign manufacturers of innovative drugs into the Ukrainian market.

The purpose of the article is to highlight the main problems of legal protection of intellectual property rights in the field of pharmacy.

Analysis of the publications that started solving this problem. The article's objective. Issues of legal protection of intellectual property rights are at the center of attention of domestic lawyers. Thus, the outlined topics became the subject of knowledge of the following scientists: V. Gordienko, Y. Kapitsa, O. Kashintseva, O. Orlyuk, T. Lyaskovsky, O. Mamun, O. Svitlychny, I. Soroka, P. Tsibulev, I. Shatov, and other scientists.

Basic content. According to Art. 2 of the Law of Ukraine "On Medicines" the term "medicines" means any substance or combination of substances (one or more active pharmaceutical ingredients and excipients) having properties and intended for the treatment or prevention of diseases in humans, or any substance or combination of substances (one or more active pharmaceutical ingredients and excipients) that may be intended to prevent pregnancy, restore, correct or alter physiological functions in humans by implementation of pharmacological, immunological or metabolic action or to establish a medical diagnosis [7, Art. 2].

Therefore, for the purposes of defining that definition, the formulation of drugs is an invention or utility, since their legal protection includes products (device, substance, strain of a microorganism, cell culture of plants and animals, etc.), process (method) and their new use. The difference between these two intellectual property rights lies in their patentability. It is true, that the invention must be new, have an inventive step and be industrially applicable, and the utility model must be new and industrially applicable [15, p. 459 and 460].

Priority, authorship and property and non-property rights to these objects are certified by a patent with a validity of 20 years for the invention and 10 years for the utility model. However, Part 4 of Art. 6 of the Law of Ukraine "On Protection of Rights to Inventions and Utility Models" the term of validity of a patent for an invention the object of which is a medicinal product, the use of which requires the permission of the relevant competent authority, may be extended at the request of the holder of this patent for a period equal to the period between the date of application and the date of receipt of such authorization, but not more than 5 years [8]. The patent grants their owners exclusive property rights to allow the use of a patented invention (utility model) or to prevent the misuse of such an object, including prohibiting such use [15, Art. 424].

The use of the invention (utility model) is recognized, first, the manufacture of a product using a patented invention (utility model), the use of such a product, offering for sale, including through the Internet, sale, import (importation) and other introduction into civil circulation or storage for such purposes; secondly, the use of the patent protected process or the offering of it for use in Ukraine, if the person offering the process knows that its use is prohibited without the consent of the patent owner or, in the circumstances, it is obvious [8, Part 2 of Art. 28].In addition, a product or process is recognized as being produced or made using a patented of the invention (utility model) if each feature included in an independent formula of the invention (utility model), or equivalent feature was used. However, the legislator also provides for cases where the exclusive property rights of the patent holder of medicines may be forcibly alienated. Thus, in order to ensure public health, defense of the state, environmental security and other interests of society, the Cabinet of Ministers of Ukraine, according to Art. 30 of the Law of Ukraine "On Protection of Rights to Inventions and Utility Models" may allow the use of a patented invention (utility model) to a designated person without the consent of the patent owner in the case of his unjustified refusal to issue a license to use the invention (utility model).

Forced alienation of intellectual property rights for medicinal products is provided not 
only by the rules of national law, but also by international provisions. In accordance with the basic agreement of the World Trade Organization (of which Ukraine has been a member since 2008) - the Agreement on Trade-Related Aspects of Intellectual Property Rights of April 15, 1994 (hereinafter referred to as the TRIPS Agreement), our country has committed itself to abide by the provisions of the TRIPS Agreement, in which (art. 31) provides for the right to use a patent without the permission of the patentee by the government of the Member State of the agreement or by a third party with the permission of the government in case of emergency in the country or in other circumstances of extreme necessity $[12 ; 14 ; 9]$.

Since 2016, Ukraine has been able to use the compulsory licensing mechanism for patented medicines to address health problems, taking into account specific circumstances, its own capabilities and needs [14]. This licensing of drugs, as O. Kashintsev notes, helps to increase the availability of pharmaceutical products to consumers as a result of the entry into circulation of innovative drugs at a more affordable price, to enhance the exchange of modern technologies with other members of the World Trade Organization, to increase the capacity of the domestic pharmaceutical sector 2.8].

The use of compulsory alienation of rights to the patented invention (utility model) is provided by Art. 5 of the Paris Convention for the Protection of Industrial Property, which Ukraine ratified on December 25, 1991. In accordance with the provision of that article, each country of the Union has the right to take legislative measures providing for compulsory licenses to prevent abuses that may result from the exercise of exclusive rights conferred by an exclusive right, providef by a patent. [3].

The legal basis and the possibilities for granting a compulsory license are also defined in the health legislation. Thus, by making changes in 2011 to Art. 9 of the Law of Ukraine "On Medicines", the legislator, in order to ensure public health, authorized the Cabinet of Ministers of Ukraine to authorize the use of a patented invention relating to such preparation to a person without the consent of the patent owner [6].

To accomplish this task, the Government approved in 2004 the Procedure for granting the Cabinet of Ministers of Ukraine permission to use the patented invention (utility model) or the registered topography of the integrated circuit, and 2013 - the Procedure for granting the Cabinet of Ministers of Ukraine permission to use the patented invention (utility model) with regard to a medicinal product $[4 ; 5]$. The Order of 2004 defines the procedure for considering a request for the Cabinet of Ministers of Ukraine to authorize the use of a patented invention (utility model) or registered topography of the integrated circuit without the consent of the holder of the respective patent, but with the payment of compensation to him, authorizing the use of a patented invention (utility model) relating to a medicinal product without the consent of the patent owner and the payment of compensation.

Compulsory alienation of property rights to intellectual property are based on problems related to health care, combating HIV infection, AIDS and other socially dangerous diseases, if they are documented, namely the presence of the following circumstances: the patent owner cannot satisfy the need for appropriate a medicinal product by the forces and capacities commonly used to produce such a medicinal product; the patent owner unreasonably denied the applicant in obtaining a license to use the invention (utility model) [5]. The formulation of the grounds for "public health" for the compulsory licensing of a patented invention, according to I. Soroka, may in the future become an instrument of pressure on pharmaceutical market participants during tendering, since any purchase of medicines for public funds will certainly be carried out for the purpose of ensuring the health of the population [1]. World practice notes the use of compulsory alienation of intellectual property rights subject to medicinal products only in extreme cases, in particular: the threat of an epidemic (as envisaged in the United States), antiretroviral drugs (Malaysia), for the treatment of AIDS and cardio- vascular diseases (Thailand) [1]. Abuse of compulsory licensing of medicines creates economic constraints, for example in Thailand - blacklisting countries that violate intellectual property rights.

However, in case of compulsory licensing of a patented intellectual property object, the Government shall pay the patentee compensation at the expense of the person to whom such authorization is granted. Its size is calculated depending on the economic value of the invention (utility model) [5]. In order to overcome the problems identified and to implement the European experience in the legal protection of intellectual property rights, the object of which is pharmaceutical products, Ukraine has undertaken to harmonize the national system of protection and protection of intellectual property rights in accordance with Ch. 9 "Intellectual property" of the Ukraine-EU Association Agreement [13]. According to Art. 230 of the said Agree- 
ment, Ukraine and the EU should provide the fair and equitable measures, procedures and remedies necessary to ensure the protection of intellectual property rights.

In doing so, these measures and safeguards must be effective and dissuasive and applied in such a way as to avoid obstruction of legitimate trade and ensure that they are protected against abuse.

In order to implement European standards of living in Ukraine and to step up Ukraine to the leading positions in the world in 2015, the President of Ukraine approved the Sustainable Development Strategy "Ukraine 2020" [10], according to which intellectual property protection reform is envisaged.

In order to fulfill the objectives of this Strategy, the Cabinet of Ministers of Ukraine in 2016 approved the Concept of reforming the state system of legal protection of intellectual property in Ukraine [11]. It should be noted that the main prerequisites for the implementation of this reform were the imperfect system of public administration in the field of intellectual property, which is not able to make significant progress in the adaptation of the legislation in the field of intellectual property to the current political and economic conditions.

This Concept also points to the need to improve the national regulatory framework and harmonize it with EU norms by amending legislation on: the legal protection of intellectual property rights in the light of the experience of EU countries; the order of allocation of the rights to these objects, including those created by the budget; protection of intellectual property rights; strengthening criminal and administrative liability for violation of these rights.

In order to establish an effective mechanism for combating counterfeit and counterfeit products, including medicines, the Ukrainian government has pledged to create an optimal, effective and high-quality state intellectual property legal system that will create a transparent public model of overcoming existing challenges and risks, and offer tools intellectual property as an incentive for the development of related economic and social factors.

Conclusions. Therefore, summarizing the above said, let us point out that the main problems of protection of intellectual property rights in the domestic pharmaceutical industry are, in particular: inefficiency of the state policy on the development of innovative medicines; lack of a transparent and comprehensible mechanism for issuing compulsory licenses for patented inventions; public awareness of the effectiveness of health care innovations for both the state and the patient; limited access to innovative medicines and treatments for Ukrainian patients. In order to overcome the problems outlined and to take into account Ukraine's European integration, our state has undertaken to harmonize the national system of protection and protection of intellectual property rights in accordance with Sec. 9 "Intellectual Property" of the EU-Ukraine Association Agreement. Establishing an effective mechanism for the protection of intellectual property rights for medicinal products will stimulate the development of innovative pharmaceutical products. After all, the development of modern medicines requires the enormous funds involved, which require guarantees for the protection of their investments and intellectual property rights for both domestic and foreign pharmaceutical manufacturers. Therefore, the introduction of an effective national system of legal protection of intellectual property rights will have a positive impact on the innovative attractiveness of Ukraine.

\section{References:}

1. Захист прав інтелектуальної власності: чи стане фармринок привабливим для інвесторів? URL: https://www.apteka.ua/article/262997 (дата звернення: 01.12.2019).

2. Кашинцева О. Ю. Примусове ліцензування винаходів у сфері фармації: перспективи для України та досвід ЄС. Теорія і практика інтелектуальної власності. 2016. № 6. С. 5-9.

3. Паризька конвенція про охорону промислової власності від 20 березня 1883 року. Зібрання чинних міжнародних договорів України. 1990. № 1.320 с.

4. Про затвердження Порядку надання Кабінетом Міністрів України дозволу на використання запатентованого винаходу (корисної моделі) чи зареєстрованої топографії інтегральної мікросхеми: постанова Кабінету Міністрів України від 14 січня 2004 р. № 8. Офіційний вісник України. 2004 р. № 2. Ст. 38.

5. Про затвердження Порядку надання Кабінетом Міністрів України дозволу на використання запатентованого винаходу (корисної моделі), що стосується лікарського засобу: Постанова Кабінету Міністрів України від 4 грудня 2013 р. № 877. Офіційний вісник України. 2013. № 97. С. 10. Ст. 3577.

6. Про внесення змін до статті 9 Закону України «Про лікарські засоби»: Закон України від 3 листопада 2011 р. № 3998-VI. Відомості Верховної Ради Украӥни. 2012. N 23. Ст. 239.

7. Про лікарські засоби: Закон України від 04.04.1996 № 123/96-ВР. Відомості Верховної Ради Украӥни. 1996. № 22. Ст. 86.

8. Про охорону прав на винаходи і корисні моделі: Закон України від 15 грудня 1993 р. № 3687-XII. Відомості Верховної Ради України. 1994. № 7. Ст. 32.

9. Про прийняття Протоколу про внесення змін до Угоди ТРІПС: Закон України 3 лютого 
2016 p. № 981-VIII. Відомості Верховної Ради. 2016. № 12. Ст.133.

10. Про Стратегію сталого розвитку «Україна - 2020»: Указ Президента України від 12 січня 2015 р. № 5/2015. Офіиійний вісник Президента України. 2015. № 2. С. 14. Ст. 154.

11. Про схвалення Концепції реформування державної системи правової охорони інтелектуальної власності в Україні: Розпорядження Кабінету Міністрів України від 1 червня 2016 р. № 402-p. Офіціийний вісник України. 2016. № 44.48 с. Ст. 1625.

12. Протокол про вступ України до Світової організації торгівлі від 5 лютого 2008 p. Офіціийний вісник України. 2010. № 24. 161 с. Ст. 970.

13. Угода про асоціацію між Україною, 3 однієї сторони, та Європейським Союзом, Європейським співтовариством з атомної енергії і їхніми державами-членами, з іншої сторони від 27 червня 2014 року. Офіційний вісник України. 2014. № 75. Т. 1. 83 с. Ст. 2125.

14. Угода про торговельні аспекти прав інтелектуальної власності від 15 квітня 1994 року. Офіиійний вісник Украӥни. 2010. № 84. С. 503. Ст. 2989.

15. Цивільний кодекс України: Закон України від 16 січня 2003 р. № 435-IV. Вiдомості Верховної Ради Украйни. 2003. № 40-44. Ст. 356.

16. Frank Lichtenberg. The Impact of New Drug Launches on Longevity: Evidence from Longitudinal, Disease-Level Data from 52 Countries, 1982-2001. Columbia University.

Received to editorial office 04.12.2019

1. Zakhy`st prav intelektual'noyi vlasnosti: chy' stane farmry'nok pry`vably`vy'm dlya investoriv? [Protecting Intellectual Property Rights: Will Pharmaceutical Market Attractive to Investors?] URL: https://www.apteka.ua/article/262997 (visited on: 01.12.2019). [in Ukr.]

2. Kashy`nceva, O. Yu. (2016) Pry’musove licenzuvannya vy'naxodiv u sferi farmaciyi: perspekty'vy' dlya Ukrayiny' ta dosvid YeES [Compulsory licensing of inventions in the field of pharmacy: prospects for Ukraine and EU experience]. Teoriya i prakty 'ka intelektual noyi vlasnosti. № 6. S. 5-9. [in Ukr.]

3. Pary'z'ka konvenciya pro oxoronu promy`slovoyi vlasnosti [The Paris Convention for the Protection of Industrial Property] vid 20 bereznya 1883 roku. Zibrannya chynnykh mizhnarodnykh dohovoriv Ukrayiny. 1990. № 1.320 s. [in Ukr.]

4. Pro zatverdzhennya Poryadku nadannya Kabinetom Ministriv Ukrayiny` dozvolu na vy'kory`stannya zapatentovanogo vy'naxodu (kory`snoyi modeli) chy`zareyestrovanoyi topografiyi integral'noyi mikrosxemy' [On approval of the Procedure for granting the Cabinet of Ministers of Ukraine permission to use a patented invention (utility model) or registered topography of the integrated circuit]: postanova Kabinetu Ministriv Ukrayiny` of $14^{\text {th }}$ of january 2004. № 8. Oficijny ’ visny`k Ukraviny’ 2004. № 2. p. 38. [in Ukr.]

5. Pro zatverdzhennya Poryadku nadannya Kabinetom Ministriv Ukrayiny` dozvolu na vy`kory`stannya zapatentovanogo vy`naxodu (kory`snoyi modeli), shho stosuyet`sya likars kogo zasobu 「On approval of the Procedure for granting the Cabinet of Ministers of Ukraine permission to use a patented invention (utility model) for a medicinal product]: Postanova Kabinetu Ministriv Ukrayiny` of $4^{\text {th }}$ of Decenber 2013 r. № 877. Oficijny jo visny`k Ukrayiny`. 2013. № 97. p. 10. p. 3577. [in Ukr.]

6. Pro vnesennya zmin do statti 9 Zakonu Ukrayiny` «Pro likars`ki zasoby`» [On Amendments to Article 9 of the Law of Ukraine "On Medicines": Law of Ukraine]: Zakon Ukrayiny" of 3d November 2011. № 3998-VI. Vidomosti Verkhovnoyi Rady`Ukrayiny'. 2012. N 23. p. 239. [in Ukr.]

7. Pro likars`ki zasoby` 「On medicinal products]: Zakon Ukrayiny` of 04.04.1996 № 123/96-VR. Vidomosti Verxovnoyi Rady`Ukrayiny`. 1996. \# 22. St. 86. [in Ukr.]

8. Pro okhoronu prav na vy`naxody`i kory`sni modeli [On the protection of rights to inventions and utility models]: Zakon Ukrayiny' of $15^{\text {th }}$ of December 1993. № 3687-XII. Vidomosti Verkhovnoyi Rady`Ukrayiny`. 1994. № 7. p. 32. [in Ukr.]

9. Pro pry 'jnyattya Protokolu pro vnesennya zmin do Ugody` TRIPS [On Adoption of the Protocol of Amendment to the TRIPS Agreement:]: Zakon Ukrayiny` 3 February 2016 . № 981-VIII. Vidomosti Verkhovnoyi Rady’ Ukrayiny. 2016. № 12. p.133. [in Ukr.]

10. Pro Strategiyu stalogo rozvy 'tku «Ukrayina - 2020» [On the Sustainable Development Strategy "Ukraine 2020"]: Ukaz Prezy`denta Ukrayiny` of $12^{\text {th }}$ of January 2015 r. \# 5/2015. Oficijny ‘ visny`k Prezy`denta Ukrayiny'. 2015. № 2. art. 14. p. 154. [in Ukr.]

11. Pro skhvalennya Koncepciyi reformuvannya derzhavnoyi sy`stemy` pravovoyi okhorony` intelektual noyi vlasnosti v Ukrayini [On approval of the Concept of reforming the state system of legal protection of intellectual property in Ukraine]: Rozporyadzhennya Kabinetu Ministriv Ukrayiny` of $1^{\text {st }}$ of June 2016. № 402. Oficijny `j visny `k Ukrayiny’. 2016. №44. 48 art. p. 1625. [in Ukr.]

12. Protokol pro vstup Ukrayiny` do Svitovoyi organizaciyi torgivli [Protocol on Ukraine's accession to the World Trade Organization] vid 5 lyutoho 2008. Oficijny ’j visny `k Ukrayiny`. 2010. № 24. 161 art. p. 970. [in Ukr.]

13. Ugoda pro asociaciyu mizh Ukrayinoyu, z odniyeyi storony`, ta Yevropejs`ky`m Soyuzom, Yevropejs'ky`m spivtovary 'stvom $z$ atomnoyi energiyi i yixnimy` derzhavamy'-chlenamy', $z$ inshoyi storony' ‘Association Agreement between Ukraine, of the one part, and the European Union, the European Atomic Energy Community and their Member States, of the other part,] vid 27 chervnya 2014. Oficijny ‘j visny 'k Ukrayiny'. 2014. № 75. T. 1.83 art. p. 2125. [in Ukr.]

14. Ugoda pro torgovel'ni aspekty` prav intelektual'noyi vlasnosti 「Agreement on Trade-Related Aspects of Intellectual Property Rights] of $15^{\text {th }}$ of April 1994 . Oficijny`j visny`k Ukrayiny`. 2010. № 84. art. 503. p. 2989. [in Ukr.]

15. Cy`vil'ny`j kodeks Ukrayiny` [Civil Code of Ukraine]: Zakon Ukrayiny` of $16^{\text {th }}$ of January 2003. № 435-IV. Vidomosti Verkhovnoyi Rady` Ukrayiny’. 2003. № 40-44. p. 356. [in Ukr.] 
16. Frank Lichtenberg. The Impact of New Drug Launches on Longevity: Evidence from Longitudinal, Disease-Level Data from 52 Countries, 1982-2001. Columbia University. [in Eng.]

\section{Summary}

The article highlights topical problems of protection of intellectual property rights in the domestic pharmaceutical industry. The effectiveness of the use of innovative medicines in the field of health is revealed. Having analyzed the norms of international and national legislation, the content of pharmaceutical products as an object of intellectual property rights in Ukraine is revealed and the state of the national legal mechanism of protection of intellectual rights in the field of pharmacy is determined. Using systemic and formal-logical methods, the procedure of compulsory licensing of patented inventions (utility models) is characterized and the main problems of its realization are formed. It has been identified that the main problems in the protection of intellectual property rights in the pharmaceutical sector include: public awareness of the effectiveness of health care innovations for the state and the patient; limited access of Ukrainian patients to innovative pharmaceutical products. inefficiency of the state policy on the development of innovative medicines; the lack of a transparent and understandable mechanism for the compulsory licensing of patented inventions to all interested parties.

In order to overcome these problems, it is proposed to harmonize the national system of protection and protection of intellectual property rights in accordance with the Association Agreement between Ukraine and the EU.

Keywords: medicines, intellectual property rights, protection of rights, pharmaceutical industry.

UDC 341.96

DOI 10.31733/2078-3566-2019-5-157-163

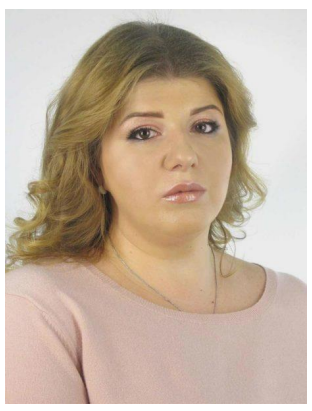

Krystyna REZVOROVYCH ${ }^{\odot}$

$\mathrm{Ph} . \mathrm{D}$

(Dnipropetrovsk State University

of Internal Affairs)

\section{LEGAL STATUS OF TRANSNATIONAL CORPORATIONS IN PRIVATE INTERNATIONAL LAW}

КОРстина Резворович. ПРАВОВИЙ СТАТУС ТРАНСНАЦІОНАЛЬНИХ КОРПОРАЦІЙ В МІЖНАРОДНОМУ ПРИВАТНОМУ ПРАВІ. КЛЮчОВою тендеНцією сучасних міжнародних відносин $є$ глобалізація світового господарства, лібералізація торгівлі $\mathrm{i}$, як наслідок, інтернаціоналізація капіталу та розвиток міжнародного підприємництва, чому активно сприяє науково-технічний прогрес і новітні технології.

Стаття присвячена проблематиці правового статусу транснаціональних корпорацій у міжнародному приватному праві. Зокрема, 3 урахуванням сучасної доктрини, національного законодавства і міжнародних документів. В статті досліджується поняття транснаціональної корпорації 3 урахуванням iї якісних і кількісних характеристик. Аналізуються положення документів ООН Проект Кодексу поведінки транснаціональних корпорацій 1983 року і Проект норм, що стосуються обов'язків транснаціональних корпорацій та інших підприємств в області прав людини 2003 р.; СНД Конвенція про транснаціональні корпорації 1998 року, а також акти Європейського Союзу.

Розкрито особливості правового регулювання статусу транснаціональних корпорацій, зокрема права, обов'язки, відповідальність, порядку створення і припинення діяльності. Специфіка правового статусу ТНК зумовлена тим, що правове регулювання їхньої діяльності здійснюється на основі норм національного законодавства кількох держав (держави реєстрації, держави розташування), двосторонніх угод, багатосторонніх договорів та міжнародних рекомендаційних актів. На сьогодні, на міжнародному рівні не вдалося прийняти юридично обов'язковий акт, в якому наводяться вичерпні ознаки ТНК, їхні права та обов'язки. У зв'язку з цим, кваліфікація утворення як ТНК залишається складним теоретичним і практичним завданням. Відсутність такого акта пояснюється неспроможністю держав віднайти компромісний підхід щодо ключових положень, що стосуються їхнього правового статусу. Це слід розглядати як негативне явище, оскільки підходи держав щодо статусу ТНК можуть бути суттєво відмінними і створювати бар'єри для руху іноземного інвестування

В умовах відсутності єдності регулювання статусу транснаціональних корпорацій в законодавстві держави наголошується на необхідності прийняття універсального міжнародного договору.

Ключові слова: транснаціональна корпорація, ТНК, транснаціональна група, багатонаціональна корпоращія, мультинаціональна корпорачія, права і обов'язки транснаціональних корпорачій, статус трансначіональних корпорачій, міжнародне приватне право.

(C) Rezvorovych K., 2019

ORCID iD: https://orcid.org/0000-0003-1183-613X

goldkristina@gmail.com 